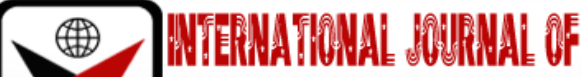

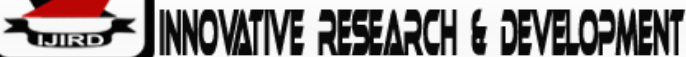

ISSN 2278 - 0211 (Online)

\section{Improving Sustainability of Food Security Irrigation Projects by Taking Corrective Action after Participatory Monitoring and Evaluation in Kitui County, Kenya}

\begin{tabular}{|c|}
\hline Douglas Ogiki Rogito \\
Ph.D. Student, Department of Continuing and Distance Education, \\
University of Nairobi, Kenya \\
Timothy Maitho \\
Professor, Department of Public Health, Pharmacology and Toxicology, \\
University of Nairobi, Kenya \\
Dr. Ann Nderitu \\
Senior Lecturer, Department of Continuing and Distance Education, \\
University of Nairobi, Kenya
\end{tabular}

\begin{abstract}
:
Food supply is less than food demand in Kitui County as population keeps increasing. This lack of food leads to malnutrition, poor health and even death to human beings and animals both domestic and wild. Agriculture is the key food source in Kitui County in the republic of Kenya. Occasionally residents buy food quantities from neighboring Arid and semi-arid areas counties which is not a reliable source because they face similar challenge. Many interventions to improve food security has been put in place and one such is irrigation by the local county and National government initiated through National irrigation Board but sustainability of these projects is a great concern in Kitui County. Despite the irrigation projects setup still biting is food insufficiency which persists. One approach to improve sustainability of irrigation projects is carrying out participatory monitoring and evaluation and then taking corrective action which could also lead to ownership and then improved sustainability. This was the objective of the study which was to assess if taking corrective action after Participatory Monitoring and evaluation (PME)influence project sustainability. The study used descriptive survey and correlation designs in order to collect data from 316 respondents who were selected using stratification, judgmental and purposeful with strict randomization methods. Questionnaires were administered and interviews were conducted on selected respondents on appointed dates. Data was analyzed using Statistical Package for Social scientist (SPSS) version 25.0in order to get descriptive statistics also correlation coefficients were got in order to get association and degree of strength. Testing of hypothesis was done using linear regression. The study findings show thata big percentage (56.3\%) of the respondents were aged between 31 to 40years.Majority of the respondents were females and their highest-level of education was up to primary school. The respondents agreed that PME data collection and taking corrective action were not done. Taking corrective action had a weak influence on sustainability with a correlation coefficient (r)of 0.33 which only explains $10.9 \%$ of project sustainability. It's recommended that farmers should be trained more through seminars and vocational institutions in order to empower them with skills. Also, farmers should be encouraged to participate in irrigation projects as they can have a sense of ownership. Infrastructure should be improved in order to access markets and a PM \& Eunit should be set up in irrigation projects in order to spear data collection and analysis and guide projects towards sustainability. This is significant because it will improve sustainability and thus more food supply reducing malnutrition rates and death among people and animals.
\end{abstract}

Keywords: Participatory monitoring and evaluation, Food security, taking corrective action, irrigation, Sustainability, Projects, management

\section{Background to the Study}

Problem of food supply is linked to many issues and it is time to rethink how we grow, share and consume our food. If done right, agriculture, fisheries and forestry can provide nutritious food for all people and generate decent incomes, while supporting people-centered rural development and protecting the environment (UN,2013).

Climate change is putting more pressure on the resources we depend on and increase risks associated with disasters such as droughts and floods. The UN (2013) advised that profound change of the global food and agriculture system is needed if we are to feed today's 925 million hungry and the additional 2 billion people expected by 2050. 
The current food security crisis in the Greater Horn of Africa is a stark reminder that insufficient attention has been given to addressing the root causes of vulnerability in the Arid and Semi-Arid Lands (ASALs) of this region. It is also apparent that it is not drought but rather vulnerability during drought in the ASALs which has thrown the Region into repeated food crises. One such ASA Larea is Kitui County in Kenya.

Kitui County is the sixth largest County in terms of size and covers an area of 30,520 square kilometers. It is $11^{\text {th }}$ in population size of 1,000,012 based on 2009 census which continues to grow. The County is diverse with some areas being Semi-arid and mostly dry, while others are fairly arable, (Kitui County,2015).

Thousands of residents of Kitui County living in Mwingi, Kitui East and Lower Yattasub counties were in need of relief food following massive crop failure in 2013(OCHA,2013). Over 80\% of the season's crops failed owing to erratic rainfall. The county government of Kitui has responded to this food insecurity by using various strategies.Kitui County government unveiled an ambitious plan to fast-track development in the Region termed "Kitui Marshall Plan (CIDP,2014). It is set to construct 2,400 sand dams across the county in order to provide water for irrigation and domestic use (KCG,2015). This initiative is meant to increase water for domestic, livestock, irrigation and tree planting. More earth dams and boreholes are planned in order to ensure Residents have access to water (CIDP,2014). Food in small quantities is also purchased from neighboring Counties which are also ASAL and hence not a reliable source.

On Irrigation projects, the County Government has allocated Sh320 million for water and irrigation projects in the County in the coming financial year, (FEWS, 2015.The National Government is using NIB andhas set up six irrigation projects which are facing many operational challenges. The degree of sustainability is still a great concern because food insufficiency is high in the County. In the other parts of the county without irrigation the main economic activity is subsistence farming of crops such as maize, beans, pigeon peas, sorghum, millet, cassava and livestock keeping. The rainfall pattern is bi-modal with long rains falling in the months of March to May. And it is usually very erratic and unreliable. The short rains which form the second rainy season fall between October and December and is more reliable, (Kitui County, 2015)

\subsection{Statement of the Problem}

Food insecurity in Kenya is of concern since more food is needed but little food is produced. The population keeps increasing in all its 47 Counties. In Kitui County malnutrition is high and is still a challenge. Malnutritionis measured as the proportion of children with mid-upper arm circumference (MUAC) of less than 135 millimeters (mm). There is continued support of nutrition supplementation programmes along with household food access (FEWS,2015). Supplementary nutrition programmes still continue across the county. Irrigation tries to improve food production in order to meet the pressing problem of food.

In Kitui County food insufficiency is noted regularly where food aid and supplementation come in to assist a worsening situation. Agriculture is the main player as food source. Sometimes Residents buy food from neighboring ASAL counties which is not also reliable. Thus, food supply is less than food production. Many interventions are in place in order to increase food production. The Government of Kenya through National Irrigation Board (NIB) set up irrigation projects in order to improve food production and address food insecurity situation in Kitui County. These projects are facing many challenges like low food production, being nonoperational and very few farmers participate in the projects hence it appears they are not sustainable. Participatory Monitoring and Evaluation (PME) is a tool which if adopted it can increase food production. Through data collection in PME analysis and then taking corrective action the projects are expected to be sustainable. The farmers who are directly affected if they participate in data collection and analysis then the main problems of the project can be identified easily. This can improve project sustainability for more food production the County.

\subsection{Objective of the Study}

Objective of the study was to asses if taking corrective action is done after data collection and analysis in order for the project to proceed in a sustainable direction.

\subsection{Study Question}

The study question drawn from study objective is: In which ways does taking PME corrective action influence sustainability of irrigation projects in Kitui County?

\subsection{Study Significance}

The study recommendations if implemented will reduce loss of lives in ASALs, attainment of higher food projects sustainability thus longer food supply that will reduce recurrence rate of food shortage, improve and hasten implementation of irrigation projects, show need to involve primary stakeholders in project Monitoring and appraisal for sustainability, better and efficient decisions can be made by policy makers that will increase chances of projects success.

\subsection{Study Limitations}

The study would have met obstacles such as some respondents would have given questionnaires to other people to fill on their behalf, thus the researcher administered the questionnaires personally. Respondents would have given limited information hence they were given assurance of privacy and confidentiality by researcher and a covering letter was used assuring them of confidentiality. Respondents' especially local farmers would not be able to read English language so a translator was used. A representative sample was used for a large population of the study. Researcher and being unfamiliar to the Kitui County a guide was used to assist in data collection. 


\subsection{Theories}

The study is informed by the four theories as given as follows: Utilization focused evaluation theory is by Patton (1999) which proposes that evaluation is done with an aim of utilizing results by intended users. It outlines the utilization process, inclusive while focusing on how to get, use the PME results to improve and learn or capacity building and then take collective action. The Social learning theory by Albert Bandura, (1977) proposes observational learning or modeling that people learn by watching other people perform a certain behavior like irrigation which explains how farmers learn new irrigation tactics by watching the experts around them and success farmers met in exposure visits thus eventually imitating them.

Stakeholder theory argues that there are many parties who form stakeholders, including financiers, communities, governmental bodies, political groups even competitors to name a few where allhave capacity to affect the project. They affect projects positively and negatively so their concerns should be looked into (Miles, 2012).Participation theory proposes that when the local beneficiaries are involved in PME they get to know the world of evaluation and learn on what the project entails. In PME farmers are involved and they create meaning from what they see and do and what needs to be done to attain project goals.

\subsection{Knowledge Gaps}

The UN case studies and SDGs discussed indicate that community participation of local farmers, capacity building through education and trainings, data collection and analysis for monitoring and evaluation then utilization which is majorly taking corrective action are critical factors for project success and sustainability thus this study aimed to assess if such are done in irrigation projects in Kitui County.

\section{Literature Review}

This section has literature on UN SDGs and UN case studies. The SGRs are 17 but this study focused on two SGDs that's number one which is to end poverty in all its forms and everywhere. The decline of extreme poverty continues, but the pace has slowed, and the world is not on track to achieving the target of ending poverty by 2030 . Extreme poverty today is concentrated and overwhelmingly affects rural populations. Increasingly, it is exacerbated by violent conflicts and climate change. Tackling the remaining pockets of extreme poverty will be challenging due to their persistence and complexity-often involving the interplay of social, political and economic factors. Effective social protection schemes and policies, along with government spending on key services, can help those left behind get back on their feet and find a way out of poverty. Progress in reducing working poverty has slowed over the past five years, suggesting that efforts in this area need to be reinvigorated. The situation remains particularly alarming in sub-Saharan Africa, where theshare of working poor stood at 38 per cent in 2018. In least developed and landlocked developing countries, at least one quarter of workers live in extreme poverty despite having a job. Employed young people (between 15 and 24 years of age) are more likely to be living in poverty, with a working poverty rate that is double that of adult workers(SDG report 2019)

The second SDG is to end hunger, achieve food security and improved nutrition and promote sustainable Agriculture.

Despite earlier extended progress, the number of people suffering from hunger has been on the rise since 2014 . Stunting affects the growth and cognitive development of millions of children, while the prevalence of overweight-the other face of malnutrition - is increasing in all age groups. In the wake of conflicts, climate-induced shocks and economic slowdowns worldwide, intensified efforts are needed to implement and scale up interventions to improve access to safe, nutritious and sufficient food for all. Specifically, attention needs to be given to increasing the agricultural productivity and incomes of small-scale food producers, implementing resilient agricultural practices, and ensuring the proper functioning of markets. Finally, in ensuring that no one is left behind on the road towards zero hunger, the intergenerational cycle of malnutrition must be broken.

\subsection{UN Case Studies}

For 4 years, the city of Pully has developed several smart city projects with the moto "step by step, success by success". In 2017, it was observed that the city was ready to develop a comprehensive smart city strategy. To do that, it was important to have a "picture" or "overview" and establish a baseline scenario on the level of digitalization of the city. Therefore, it was decided that Pully would participate in the U4SSC KPIs project and adopt the U4SSC KPIs for Smart Sustainable Cities.

The United for Smart Sustainable Cities (U4SSC) initiative is a UN initiative coordinated by ITU and UNECE with the support of 14 other UN agencies. It is dedicated to achieving SDG 11: "Make cities and human settlements inclusive, safe, resilient and sustainable". . (Moreno, J and Shaw, D,2017)

The objective of this case study is to show how the City of Pully (Switzerland) has used the key performance indicators of the United for Smart Sustainable Cities (U4SSC) to identify the city's strengths, opportunities for development and challenges. One of the challenges faced was translating the result of the KPIs into an easy-to-understand manner is very important. Policymakers and citizens alike must be able to interpret the results without any specialized knowledge in order to take actions based on the results. To that end, a graph that helps to illustrate the current situation of the city based on the results of the KPIs, has been developed. (Moreno and Shaw, D,2017

\section{Research Methodology}

Research design, target population, sampling procedure and sample size, research instruments, validity and reliability, data collection, analysis and ethical issues are given in this section. 


\subsection{Research Design}

The study was based on a mixed mode approach and a description survey design was used to collect data in irrigation projects and correlation designs which assisted in assessing influence of independent variables ondependent variable. Data was collected from the respondents in the irrigation projects in order to fulfill objectives of the study (William and Trochim (2006). The researcher collected data using questionnaires and interview schedules in order to get information from selected respondents.

\subsection{Target Population}

The target population included National Irrigation Board (NIB) managers in Kitui County, Co-operative managers, Government extension officers and farmers as implementers of irrigation projects in Kitui County. Kitui County has six NIB irrigation projects from where the respondents were selected. Stratification was done at project level. The target population for the study is shown in Table 1.

\begin{tabular}{|c|c|c|c|c|}
\hline Project & $\begin{array}{c}\text { NIB Project } \\
\text { Manager }\end{array}$ & $\begin{array}{c}\text { Co-operative } \\
\text { project Managers }\end{array}$ & $\begin{array}{c}\text { Government } \\
\text { Extension Officers }\end{array}$ & Farmers \\
\hline Usueni/ Wikithuki Project & 1 & 2 & 1 & 800 \\
\hline Kalundu Project & 1 & 2 & 1 & 300 \\
\hline MandalwaProject & 1 & 2 & 1 & 60 \\
\hline Kavisuni Irrigation Project & 1 & 2 & 1 & 50 \\
\hline Wingo Irrigation Project & 1 & 2 & 1 & 30 \\
\hline Thua Model Farm & 1 & 2 & 1 & 100 \\
\hline Total & 6 & 12 & 6 & 1340 \\
\hline
\end{tabular}

Table 1: Target Population in Kitui County

Source: Maithia (2015) of National irrigation board

\subsection{Sampling Procedure and Sample Size}

Part of the accessible population was selected as sample for the study. The sample size was chosen using stratified and purposeful sampling designs with randomization. Krejcie and Morgan (1970) Table was used in order to determine 300 farmers from the target projects with a population of 1340 while the other 24 respondents were selected purposefully in order to provide the needed data as shown in Table 2.

\begin{tabular}{|c|c|c|c|}
\hline Category of Respondents & Target Population & Sampling Techniques & Sample Size \\
\hline Cooperative project manager & 12 & Purposive & 12 \\
\hline Government ext. officers & 6 & Purposive & 6 \\
\hline Farmers & 1340 & Stratified & 300 \\
\hline NIB project managers & 6 & Purposive & 6 \\
\hline Total & 1364 & & 324 \\
\hline
\end{tabular}

Table 2: Sampling Selection Methods

Farmers from various irrigation projects were stratified and 300 farmers were selected proportionally from the total population of farmers. The sample size for the farmers was selected by stratification of projects: 179 from Wikithuki, 67 from Kalundu, 22 from Thua model farm, 14 from Mandalwa,11 from Kavisuni and 7 from Wingo. Purposeful sampling of the other 24 respondents included: Cooperative project managers, government extension officers and National Irrigation Board (NIB) project managers.

\subsection{Research Instruments}

Questionnaires were used to collect qualitative and quantitative data from primary and secondary sources of the study. Research opinions data can be collected using structured closed and open ended questions since data from a wide area can be collected easily in a short time due to close ended items and individual opinions through open ended items (Kombo and Tromp ,2006).Interviews scheduleswere also used for NIB managers, Extension officers and Co-operative managers in order to get in depth information on irrigation projects as they may not get time to fill the questionnaires and not give information to the depth that was needed. Secondary information was obtained from documents in the County departments on irrigation projects.

\subsubsection{Piloting of the Instruments}

The instruments were piloted according to Mugenda and Mugenda (2008) and Connely (2008) where one to ten percent of the study sample was used for piloting. Thus, a group made of two Cooperative managers, one Agricultural extension Officer, thirty farmers and one NIB project manager were used from Mwingi West Sub County. Piloting was done before the actual study in order to identify areas that needed adjustments in the instrument for effective operations.

3.4.2. Validity of Instruments

Validity is the degree to which results obtained from the analysis represent the phenomena under study (Mugenda and Mugenda ,2008) thus validity is a subject concerning what can be measured. Content, construct and face validity was measured through a pilot study. Experience gained from pilot survey was used to fine tune and improve 
questionnaire and interview schedules. Also, expert advice was obtained from university supervisors after availing instruments items.

\subsubsection{Reliability of the Instruments}

Reliability is a measure of the degree to which a research instrument yields consistent results after repeated trials. Borg and Gall (1989) noted that an instrument is reliable if it is internally consistent or stable and if it providesconsisted results. Reliability was tested by having all questions for interview and questionnaire written down and study done at same time of a day for consistency. Reliability was also measured by using Split half method by dividing instruments into two halves after numbering them that's odds and evens and then calculate Pearson's correlation (r) between the scores of the two halves was calculated. The split halves transformed into an appropriate reliability estimates for the entire test and Spearman-Brown prophecy formula applied which is:

$\mathrm{Rx}=\frac{2 r}{1+r}$

Where $\mathrm{Rx}$ is the estimated reliability of the entire test and $\mathrm{r}$ is the Pearson correlation between the two halves. The reliability obtained was 0.9 and according to Frankel and Wallen, (2000) an alpha above 0.7 canbe accepted.

\subsection{Data Collection Procedures}

Data collection was done after getting introductory letter from the University of Nairobi and research permit from National Commission for Science, Technology and Innovation. The County irrigation officers were met and appointments were made with them after getting authorization of the study. The County irrigation officers organized a meeting with the farmers using the irrigation project chairpersons. The researcher also met area chiefs after getting permit. A date was setin order to administer questionnaires and conduct interviews in order to collect data. Maximum responses were followed as reported by Wisemans and McDonald (2009). A covering letter stating purpose of study was attached assuring participants confidentiality was attached. The instruments were examined for completeness, comprehensiveness, consistently and reliability.

\subsection{Data Analysis Techniques and Presentation}

Data is presented using Tables from dependent and independent variables in order to improve understanding (Kombo and Tromp, 2006). Tables are understood easily and compresses large amounts of data. Qualitative data was summarized and further interpretation made. The results were analyzed using Statistical Package for Social Sciences version 25.0 and Microsoft Excel 2013 in order to get correlations, means, percentages, Linear regression and frequency distributions on dependent and independent variables.

On the objective on how taking PME corrective action influences sustainability of irrigation projects data was obtained on taking PME corrective action and sustainabilitythen a correlation coefficient was obtained and nature and degree of correlation identified. Hypothesis stated belowwas tested using Linear regression model whichfollows:

- $\mathrm{H}_{0}$ : TakingPME corrective action has no influence on sustainability of irrigation projects in Kitui County

- $\mathrm{H}_{1}$ : TakingPME corrective action has influence on sustainability of irrigation projects in Kitui County

Null hypothesis was tested using Linear regression model:

$\mathrm{Y}=\mathrm{a}+\beta_{1} \mathrm{X}_{1}+\mathrm{e}$ where ;

$\mathrm{Y}=$ Sustainability of irrigation projects in Kitui County,

$\mathrm{a}=$ Constant

$\beta_{1}=$ Beta coefficient

$\mathrm{X}_{1}=$ Taking PME corrective, $\mathrm{e}=$ error term.

Qualitative data analysis was considered on improvements and suggestions was done and inferences were made from views gathered from the respondents were summarized into daily, weekly later was organized into an interim report which was later matched with quantitative information.

\subsection{Ethical Issues}

Introductory letter from the University of Nairobi was obtained and research permit from National Commission for Science, Technology and Innovation. Researcher ensured that no discomfort was caused to the respondents during data collection. The Information which collected was kept confidentially and respondents were assured of the same. The respondents participated voluntarily and after their consent, then the researcher conducted the study. The researcher trained researched assistants on how to collect data and avoid bias when interviewing and recording findings. They were also trained on how to create rapport before data collection from the respondents. Daily reviews on data collection in order to increase success rate was conducted.

\section{Results}

The findings are given following the thematic sub headings and response rate, background of the respondents, test of assumptions, analysis of sustainability, analysis of taking corrective action, inferential analysis and regression analysisis presented.

\subsection{Response Rate}

The researcher set out to interview a total of 324 respondents but only accessed 316 who were spread across six different project areas. This was a (97.5\%) response rate. 


\subsubsection{Background of the Respondents}

This section outlines the distribution of respondents by age, gender and level of education.

\subsubsection{Distribution of Respondents by Age}

The study found out that majority (56.3\%) of the respondents interviewed were between 31 years and 40 years. This was followed by those aged 51 years and above who formed $32.9 \%$ of the respondents.

\subsubsection{Distribution of Respondents by Gender and Level of Education}

Out of the 316 respondents interviewed, $62.7 \%$ were Females and $37.3 \%$ were Males.The respondents were asked to state their level of education and the responses were collated. A total of $60.4 \%$ of the respondents had primary education as their highest level of education. This was then followed by $38.9 \%$ of the respondents who had secondary as their highest level of education.

\subsubsection{Tests of Assumptions for Normality and Collinearity}

The normality and collinearity of the data which was collected is given below. The test of normality was conducted using Kolmogorov -Smirnov test statistic (KS-test) and Shapiro-Wilk test (SW-test). Normality test shows whether the data follows or does not follow a specified distribution. While carrying out this test, it was hypothesized that: $\mathrm{H}_{0}$ : The sample population was not normal.

The study used Shapiro-Wilk test which is able to detect departures from normality due to either skewness or kurtosis or both (Rizali\&Wah 2011). The null hypothesis is rejected if the value of SW-test is too small as it should lie between zero and one. The results of the KS-test and SW -test are shown in Table 3

\begin{tabular}{|c|c|c|c|c|c|c|}
\hline & \multicolumn{3}{|c|}{ Kolmogorov-Smirnov } & \multicolumn{3}{|c|}{ Shapiro-Wilk } \\
\cline { 2 - 7 } & Statistic & df & Sig. & Statistic & Df & Sig. \\
\hline Taking PME corrective action & 0.521 & 251 & 0.000 & 0.037 & 251 & 0.000 \\
\hline
\end{tabular}

Table 3: Kolmogorov-Smirnov and Shapiro- Wilk-tests

Results in Table 3 shows that in all the variables under investigation, the KS test statistic is as follows: Taking PME corrective action $=0.521 . \mathrm{SW}$ statistic is 0.037 which is between 0 and 1 andof great focus is that the variable under investigation shows that $\mathrm{p}<0.05$. This implies that the null hypothesis is rejected. It can therefore be concluded that the sample was picked from a normal population.

In the application of the Central Limit Theorem, the sample of this study was 316 respondents. This was considered relatively large and normality of the data cannot be questioned (Alam, 2010). As a precedence to use correlation and regression, the data was subjected to multicollinearity testing using the Variance Inflation Factor (VIF) and tolerance tests in the regression analysis as shown in Table 4

\begin{tabular}{|c|c|c|c|}
\hline & \multicolumn{2}{|c|}{ Coefficients } & \multirow{2}{*}{ R } \\
\hline \multirow{2}{*}{ Item } & Collinearity Statistics & \\
\cline { 2 - 4 } & Tolerance & VIF & 0.330 \\
\hline PME corrective action & 0.525 & 1.905 & 0.95 \\
\hline
\end{tabular}

Table 4: Test of Collinearity

The Values of VIF is 1.905. The value is within the criteria set by Meyer (2010), who suggested that VIF should be less than 10. The tolerance value is 0.525 . The valueis within MacKinnon (2007), criteria that suggested that tolerance value of less than 0.1 can infer multicollinearity. Garson (2008) reported that there is absence of problems with multicollinearity when variables have correlation of less than 0.8 .

\subsection{Analysis of Sustainability of the Irrigation Project}

According to the theoretical framework, Sustainability of the irrigation project was the dependent variable of study.

Sustainability of the irrigation project had ten indicators which were rated on a five-point Likert scale of 1 for Strongly disagree (SID), 2 for Disagree(D), 3 for Neutral(N), 4 for Agree(A) and 5 for Strongly agree (SA). The analysis examined the Mean Scores (MS) and Standard Deviation (SD) on the responses to statements about sustainability of irrigation projects. $M S=1$ implies that the farmers Strongly disagreed with the statement, whereas MS=5 implies that the farmers strongly agreed with the statement about sustainability of irrigation project. This is shown in Table 5 that follows: 


\begin{tabular}{|c|c|c|c|}
\hline Activity & $\mathbf{N}$ & $\begin{array}{l}\text { Mean Score } \\
\text { (MS) }\end{array}$ & $\begin{array}{l}\text { Std. Deviation } \\
\text { (SD) }\end{array}$ \\
\hline The project is accepted locally & 316 & 4.03 & 0.977 \\
\hline The project is in line with local County policies & 316 & 3.77 & 1.303 \\
\hline The project is simple to run and operate & 315 & 3.34 & 1.324 \\
\hline Local farmers are participating in running the project & 316 & 3.21 & 1.499 \\
\hline Farmers do have technical knowhow to run the project & 316 & 3.09 & 1.308 \\
\hline The project has existed for over 5 years & 315 & 2.78 & 1.637 \\
\hline There is a sustainability plan of action in use & 316 & 2.63 & 1.436 \\
\hline $\begin{array}{l}\text { The project is integrated to local leadership structures } \\
\text { such using chiefs and village elders. }\end{array}$ & 316 & 2.62 & 1.463 \\
\hline The projects have spoiled our rivers & 316 & 2.34 & 1.522 \\
\hline The project has improved farmer's lives & 316 & 2.34 & 1.481 \\
\hline The project does raise money locally for its use till now & 316 & 2.22 & 1.406 \\
\hline Project has trained members as officials & 316 & 2.21 & 1.335 \\
\hline
\end{tabular}

Table 5: Sustainability of Irrigation Project

The Table 5 shows that the farmers largely agreed with these four statements which had MS ranging from 4.03 with a SD of 0.977 to a MS of 3.21 and a SD of 1.499. In particular, there was no doubt about agreements with the statements: 'The project is accepted locally' (MS $=4.03 \mathrm{SD}=0.977$ ); 'The project is in line with local County policies' (MS =3.77SD=1.303); 'The project is simple to run and operate' (MS $=3.34 \mathrm{SD}=1.324$ ) and 'Local farmers are participating in running the project' (MS $=3.21 \mathrm{SD}=1.499$ ). It is also worth noting that farmers responses were negatively skewed on the statements: 'Project had trained members as officials' (MS=2.21SD=1.335); 'The project does raise money locally for its use till now' (M=2.22SD =1.406);'The project has improved farmer's lives' $(\mathrm{M}=2.34 \mathrm{SD}=1.481)$ and 'The projects have spoiled our rivers' (M=2.34SD =1.522).

\subsection{Analysis of How Taking PME Corrective Action Influences Sustainability of Irrigation Projects in Kitui County}

This section presents the descriptive analysis of how PME corrective action influences sustainability of irrigation projects, Correlation analysis of PME corrective action and sustainability of irrigation projects and Inferential analysis of PME corrective action and sustainability of irrigation projects.

\subsubsection{Descriptive Analysis of Taking PME Corrective Action and Sustainability of Irrigation Projects}

This study sort to examine the influence of taking PME corrective action on sustainability of irrigation projects. Descriptive statistics focusing on frequency distributions, Mean Scores and Standard Deviations were used to explore the data. Afive-point Likert Scale of 1 for Strongly disagree (SID), 2 for Disagree(D), 3 for Neutral(N), 4 for Agree(A) and 5 for Strongly agree (SA) was used to get respondents' rating of PME corrective action.

The analysis on the responses to the statements about PME corrective action is given below. In the analysis MS=1 implies that the respondents Strongly disagreed with the statement, whereas MS=5 implies that the respondents strongly agreed with the statement about taking PME corrective action as shown in Table 6

\begin{tabular}{|c|c|c|c|}
\hline Activity & $\mathbf{N}$ & $\begin{array}{c}\text { Mean } \\
\text { Score (MS) }\end{array}$ & $\begin{array}{c}\begin{array}{c}\text { Std Deviation } \\
\text { (S.D) }\end{array} \\
\end{array}$ \\
\hline Project problems were identified & 312 & 3.41 & 1.504 \\
\hline Farmers did project diagnosis & 312 & 2.75 & 1.390 \\
\hline Continuous risk assessment was done & 313 & 2.52 & 1.472 \\
\hline Possible solutions to problems were identified & 313 & 2.44 & 1.247 \\
\hline Suitable solutions were identified & 313 & 2.42 & 1.274 \\
\hline Trainings were done to farmers how to take corrective action & 313 & 2.28 & 1.462 \\
\hline Solutions were implemented to solve the problems. & 313 & 2.19 & 1.247 \\
\hline Data was collected on problems identified & 313 & 2.03 & 1.178 \\
\hline Data collected was analyzed & 313 & 1.83 & 1.146 \\
\hline $\begin{array}{l}\text { Evaluations to the project were done to see if problems were } \\
\text { solved }\end{array}$ & 313 & 1.43 & 0.826 \\
\hline
\end{tabular}

Table 6: Taking PME Corrective Action Mean Scores

From Table 6 respondents agreed to statement: Project problems were identified (MS=3.41 SD=1.504)'The respondents largely disagreed with the statement: Evaluations to the project were done to see if problems were solved $(\mathrm{MS}=1.43 \mathrm{SD}=0.826)$.

\subsubsection{Correlation Analysis of Taking PME Corrective Action and Sustainability of Irrigation Projects}

The study used Pearson's Product Moment correlation in order to determine the relationship between taking PME corrective action indicators and project sustainability of irrigation projects indicators. Correlation analysis helps in the 
understanding of the strength and direction of the relationship. Correlation values ranges from +1 to -1 . A +1 correlation indicates that correlation is positive and perfect while the -1 indicates that the correlation is negative and perfect. Correlation coefficient (r) values ranging from 0.81 to 1 are considered very strong; while 0.61 to 0.8 are considered strong; 0.41 to 0.6 are considered moderate; 0.21 to 0.4 are considered weak and 0 to 0.2 correlation indicates here is no relationship. Table 7 shows correlation coefficients of taking PME corrective action and sustainability of irrigation projects.

\begin{tabular}{|c|c|c|}
\hline & $\begin{array}{c}\text { Taking PME Corrective } \\
\text { Action }\end{array}$ & $\begin{array}{c}\text { Sustainability of Irrigation } \\
\text { Projects }\end{array}$ \\
\hline Pearson Correlation & 1 & 0.330 \\
\hline Sig. (2-tailed) & & 0.000 \\
\hline $\mathrm{N}$ & 316 & 316 \\
\hline
\end{tabular}

Table 7: Correlation Matrix for Taking PME Corrective Action and Sustainability of Projects

Table 7 shows that there was weak positive relationship $(\mathrm{r}=0.33, \mathrm{p}=0.000)$ between taking PME corrective action and Sustainability of irrigation projects.

\subsubsection{Inferential Analysis of Respondent Characteristics and Taking PME Corrective Action}

The objective of the study was to establish how taking PME corrective action influences sustainability of irrigation projects in Kitui County.In this section, the relationship between respondents' characteristics and taking PME corrective action was collated and analyzed as shown in Table 4.6.

\begin{tabular}{|c|c|c|c|c|c|}
\hline Attribute & $\begin{array}{c}\text { Pearson's } \\
\text { R }\end{array}$ & $\begin{array}{c}\text { Asymp. } \\
\text { Std. Error }\end{array}$ & $\begin{array}{c}\text { Approx. } \\
\text { T }\end{array}$ & $\begin{array}{c}\text { Approx. } \\
\text { Sig. }\end{array}$ & $\begin{array}{c}\text { Number of } \\
\text { valid cases }\end{array}$ \\
\hline $\begin{array}{c}\text { Age group by taking corrective } \\
\text { action }\end{array}$ & -0.278 & 0.062 & -5.119 & 0.000 & 316 \\
\hline $\begin{array}{c}\text { Gender by taking corrective } \\
\text { action }\end{array}$ & 0.319 & 0.055 & 5.971 & 0.000 & 316 \\
\hline $\begin{array}{c}\text { Highest level of education and } \\
\text { Taking PME corrective action }\end{array}$ & -0.259 & 0.058 & -4.744 & 0.000 & 316 \\
\hline
\end{tabular}

Table 8: Symmetric Measures of Respondent Characteristics and Taking PME Corrective Action

The findings show weak negative ( $\mathrm{r}=-0.278)$ relationship between age group and taking PME corrective action. Also there existed a weak positive $(\mathrm{r}=0.319)$ relationship between gender of respondents and taking PME corrective action. The negative weak ( $\mathrm{r}=-0.259)$ relationship was also seen between highest level of education and taking PME corrective action.

The study went further to test simple linear regression model in order to make conclusion from the hypothesis.

\subsubsection{Hypothesis}

$\mathrm{H}_{0}$ : Taking PME corrective action has no influence on sustainability of irrigation projects in Kitui County

$\mathrm{H}_{1}$ : Taking PME corrective action has influence on sustainability of irrigation projects in Kitui County Null hypothesis was tested using linear regression model:

$\mathrm{Y}=\mathrm{a}+\beta_{1} \mathrm{X}_{1}+\mathrm{e}$ where;

$Y=$ Sustainability of irrigation projects in Kitui County, $a=$ Constant, $\beta_{1}=$ Beta coefficient

$\mathrm{X}_{1}=$ Taking PME corrective, $\mathrm{e}=$ error term. The results are presented in Table 9.

\begin{tabular}{|c|c|c|c|c|c|c|c|c|c|}
\hline \multirow[t]{2}{*}{ Model } & \multicolumn{2}{|c|}{$\begin{array}{l}\text { Unstandardized } \\
\text { Coefficients }\end{array}$} & $\begin{array}{c}\text { Standardized } \\
\text { Coefficients }\end{array}$ & \multirow[t]{2}{*}{$\mathbf{t}$} & \multirow[t]{2}{*}{ Sig. } & \multirow[t]{2}{*}{$\mathbf{R}$} & \multirow[t]{2}{*}{$\mathbf{R}^{2}$} & \multirow[t]{2}{*}{$\mathbf{F}$} & \multirow[t]{2}{*}{ Sig. } \\
\hline & B & $\begin{array}{c}\text { Std. } \\
\text { Error }\end{array}$ & Beta & & & & & & \\
\hline (Constant) & 0.846 & 0.022 & & 39.308 & 0.000 & & & & \\
\hline $\begin{array}{c}\text { Taking PME } \\
\text { corrective } \\
\text { action }\end{array}$ & 0.150 & 0.024 & 0.330 & 6.205 & 0.000 & 0.330 & 0.109 & 38.498 & 0.000 \\
\hline
\end{tabular}

Table 9: Regression Analysis of Taking PME Corrective Action and Sustainability of Irrigation Projects in Kitui County

From Table 9, when $\mathrm{R}=0.33$ this shows that taking PME corrective actionhasa weak influence on sustainability of irrigation projects in Kitui County. When $\mathrm{R}^{2}=0.109$ this implies that takingPME corrective actionexplained $10.9 \%$ ofsustainability of irrigation projects in Kitui County. A test of significance at $\mathrm{p}=0.05$ show that taking PME corrective actionhas $(p=0.000)$ which is significant. Using the statistical findings, the regression model PME has influence on sustainability and should be encouraged by setting up a PME unit in order to guide its function in each project leading to higher sustainability. 


\section{Discussion, Conclusion and Recommendations}

\subsection{Introduction}

The discussion, conclusion and recommendations are given below.

\subsection{Discussion of Findings}

The findings on respondent's social factors show that more than half were aged between 31 and 40 years while they were respondents who were few above 41 years and very few were between 21 and 30 years and thus a clear indication that the youth were rarely participate in food production.

The findings on gender show that more than half of respondents were female and a small percentage were males and this shows that women are many backs in rural areas and engage in food production as house hold chores left to women. The results on education show that majority of the respondents had primary education while there were very few with secondary education and none to degree andabove. Thus, seminars and short courses to farmers are highly recommended in order to equip the locals with skills as extension officers are few in number and are hardly available to meet all farmer needs.

The findings show that respondents agreed on statement that: Project problems were identified. They were neutral onstatement: Farmers did project diagnosis and Continuous risk assessment was done. Respondents disagreed largely on the statements that: Data on PME was collected and analyzed, Possible solutions were identified and then suitable solutions were identified and trainings were done on how to take corrective action, Solutions were implemented to solve the problems and finally :Evaluations were done in order to see if project problems were solved .This shows that problems which were a concern to stakeholders are identified but continuous risk assessment was not done thus the future is not monitored. PME does not take place because those with know how lack and thus farmers do not have skills. This then affects sustainability because problems are not solved and no solution is implemented then projects sustainability is not expected.

Findings on Correlation of respondent's social factors show that there was a negative relationship between age and education with taking PME corrective but a weak positive relationship between gender of respondents with taking PME corrective action. Also, it was found that majority of the members are women. Further analysis shows taking PME corrective action has a weak influence on sustainability at $r=0.33$ and it only explains $10.9 \%$ of sustainability of irrigation projects Thus the role PME plays cannot be ignored as it is contribution is notable. The study concurs with ILRI (2011) findings which indicated that for functional mechanisms for early response needs to invest in data management systems

\subsection{Conclusion}

The following conclusions were made from the study. It is concluded that more females take part in irrigation projects in Kitui County. Most respondents had little education. Majority had primary leveleducation. PME datawasnot collected and analyzed on identified problems and thus project problems are not properly addressed even if taking corrective action plays a role in irrigation project sustainability

\subsection{Study Recommendations}

The following recommendations are from the study. It is recommended that the inhabitants Kitui County should get irrigation skills through seminars and short courses trainings or to pursue further education to higher levels as government has prioritized it through free primary and secondary education or take adult education classes. More men should be encouraged to join women in the irrigation projects as they are heads of families who have access to resources. Improving capacity building for community driven development at community level such as vocational training in technical and business skills. This will assist communities to improve their own assets and skills and allow them to improve their agricultural production potential and thus enhance their resilience to food insuffiency and increasing selfsufficiency.

Improved roads, market, water and communication infrastructures are critical since they will improve agricultural production and marketing of the produce hence trigger further food production. Increased community participation in policy decisions and resource allocation on irrigation projects does much good. It has been noted to increase project ownership which improves sustainability.

Drought is rampant in the County and there is a need to fund early response to drought, with in a conducive policy and institutional setting. For financial stability in households there is need for improved and alternative incomes through: Effective community-based animal health services, secure access to land and water so as to develop irrigation as it was also noted by Muasya (2015).

There is need for data collection in PME so that projects can take direction towards sustainability. An M\&E unit should be set in each project in order to spear the PME activities. Sustainability is embedded into projects because the communities themselves help identify the problems to be tackled, plan the projects and then implement them so by all means they should be encouraged to participate. Effective monitoring and evaluation of irrigation policy is strongly recommended for implementation.

Use of PME on irrigation projects will increase ownership and builds on project sustainability. National irrigation Board has set up irrigation projects in order to produce food which needs constant monitoring and evaluation in order to achieve sustainability and faster goal achievement. 


\section{References}

i. Alam M.M, Siwar C, Molla R.I, Toriman M.E and Talib B (2010). Socioeconomic Impacts of Climatic Change on Paddy Cultivation: An Empirical Investigation in Malaysiain.http://journals.sfu.ca/jkg/index.php/journal/article/view/57/44 (Cited on $5^{\text {th }}$ Nov 2010).

ii. Baron, R. M., and Kenny, D. A. (2009). The moderator-mediator variable distinction in social psychological research: Conceptual, strategic, and statistical considerations. Journal of Personality and Social Psychology, 51(6), 1173-1182 in http://dx.doi.org/10.1037/0022-3514.51.6.1173.

iii. Borg, W. R and Gall, M. D. (1989). Educational research. Longman: New York

iv. CIPD (2014) County Integrated Development Plan, Marshall plan for Kitui county 204/2015 Financial year in, in http://www.kitui.go.ke. (Accessed, November 2015.)

v. Connely, L.M (2008). Pilotstudies, Medsurg nursing,17(6),411-2.

vi. Fathani, T (2017) SDGs case studies, Sustainable Cities and Communities, Community-based Landslide Early Warning System as a Tool towards Sustainable Community Development on Disaster Risk Reduction, Universitas Gadjah Mada, Yogyakarta, Country: Indonesia

vii. FAO (2015) Country Briefs in http://www.fao.org/giews/countrybrief/country.jsp?code. . (Accessed in May 2017)

viii. FEWS. (2015), Food Security Outlook, inhttp://www.fews.net/east-africa/kenya/food-securityoutlook.(Accessed,April-2018.)

ix. Frankel, J.R. and Wallen N.E, (2000). How to design and evaluate research in education. McGraw-Hill:, Boston.

X. Garson, D. G. (2008).Factor Analysis: Statnotes. Public Administration Program.North Carolina State University.Sage. Washington.

xi. ILRI ,2011),in http://www.ilri.org/ilrinews/index.php/archives/tag/asals.(Accessed, November 2018.)

xii. Kitui County,(2015 )Country Development Plan , in http://www.kitui.go.ke. . (Accessed in May 2015.)

xiii. Kombo.D,and Tromp, D (2006).An Introduction Proposal and Thesis Writing , Paulines Publications, Nairobi.

xiv. MacKinnon,D.P ,Lockwood C.M ,Brown,C.H and Wang Hoffman J.M , (2007) ,The in-termediate endpoint effect in logistic and probit regression, Clinical Trials 4 ,pp499-513.

xv. Maithia (2015).Irrigation projects in Kitui In www.NIB.go.ke. Retrieved on 20 ${ }^{\text {th }}$ April, 2015.

xvi. Meyer .B,D(2010). Econometrica Volume 58, No. 4.The Econometric Society. New York.

xvii. Moreno,J and Shaw,D(2017) SDGs Case Studies,Pully in Switzerland: Standards for Sustainable Cities and Communities , Switzerland ,University of Manchester (UK) and University of Chile (Chile) .

xviii. Muasya ,C., (2015.)Handling-food-security ,http://awcfs.org/kw/article/women-in-kitui-county-findalternative-means-to-handling-food-security.(Accessed,April-2016.)

xix. Mugenda, O. M. and Mugenda, A. G. (2008).Research Methods: Quantitative and Qualitative Approaches. Acts Press, Nairobi.

xx. Rizali, N. and Wah, Y.B. (2011).Power Comparisons of Shapiro-Wilk, Kolmogorov-Smirnov, Lilliefors and Anderson-Darling Tests.Journal of Statistical Modeling and Analytics.Scientific Research Publishing.

xxi. UN Office for the Coordination of Humanitarian Affairs( OCHA,2013 ),Policy Development and Studies, Normative decisions, General Assembly resolution 46/1823rd Edition . Branch Policy and Studies Series 2013.

xxii. United Nations (2013),Improving food systems in the world in www.un org /food systems . (Accessed in October 2014.)

xxiii. United Nations University(2015),Food security in Africa ,http://archive.unu.edu/unupress/unupbooks. (Accessed in March 2015.).

xxiv. WFP (2015,) Kenya-family-farming inhttps://www.wfp.org/stories/kenya-family-farming-transforminglives.(Accessed in June2018.)

xxv. William M.K and Trochim (2006).The Research Methods, Knowledge Base, Second Edition,:Atomic dog publisher: NewYork.

xxvi. Wiseman.F and McDonald. P,(2009.)Towards the Development of Industry ,Standards of Response and Nonresponse Rates. Report 80-101., MA: Marketing Science Institute, Cambridge.

xxvii. SDGs (2019),The Sustainable Development Goals Report2019,UN 